\title{
PENGEMBANGAN PERANGKAT PEMBELAJARAN MATEMATIKA MODEL LEARNING CYCLE 7E SISWA KELAS X SMA TAHAP PRELIMINARY RESEARCH
}

\author{
Sri Ulfa Insani ${ }^{1}$, Djamilah Bondan Widjajanti ${ }^{2}$ \\ ${ }^{1}$ Universitas Pahlawan Tuanku Tambusai, Jalan Tuanku Tambusai No. 23 Bangkinang. \\ ${ }^{2}$ Universitas Negeri Yogyakarta, Jalan Colombo No. 1 Karang Malang, Yogyakarta. \\ sriufainsanishelly@gmail.com
}

\begin{abstract}
The aim of this research is to produce trigonometry instructional package with learning cycle 7e model based on the aspect of validity, practicality, and effectiveness in terms of problem solving skill and curiosity of $10^{\text {th }}$ grade senior High School students. There are seven phases of learning cycle 7e model consisting of elicit, engage, explore, explain, elaborate, evaluate, and extend. The developed instructional package consists of lesson plans and worksheets. This study was research and development. The developing model in this research used ADDIE's model (Analyze, Design, Develop, Implement, and Evaluate). The research instruments were validation sheets, teacher assessment quistionnaire, student assessment quistionnaire, observation sheets for learning implementation, problem solving skill tests, and curiosity questionnaire. The instructional package is effective if the percentage of students who meet the completion of a classical test on problem-solving skills tests reaches at least $75 \%$, and if the percentage of questionnaire results students meet the high category with minimum $75 \%$. The first step of this research is to carry out the analysis with the steps of conducting analysis of needed, analysis of material, and analysis of student character. In this step, lesson plans and worksheets were designed with learning cycle 7e model. To determine validity criteria, a validation sheet is used based on the expert's assessment. Then for the practicality used teacher assessment quistionnaire, student assessment quistionnaire, and observation sheets for learning implementation. Next to determine the effectiveness criteria seen from the results of student scores by giving problem solving skill tests, and curiosity questionnaire.
\end{abstract}

Keywords: Learning Cycle 7e Model, Instructional Package

\begin{abstract}
Abstrak
Penelitian ini bertujuan untuk menghasilkan perangkat pembelajaran trigonometri dengan model learning cycle $7 e$ berdasarkan aspek kevalidan, kepraktisan, dan keefektifan ditinjau dari kemampuan pemecahan masalah dan rasa ingin tahu siswa kelas X SMA. Pembelajaran dengan model learning cycle 7e terdiri dari tujuh tahapan yaitu elicit, engage, explore, explain, elaborate, evaluate, dan extend. Perangkat pembelajaran yang dikembangkan terdiri dari RPP dan LKS. Penelitian ini merupakan penelitian pengembangan. Model pengembangan yang digunakan adalah model ADDIE (Analyze, Design, Develop, Implement, dan Evaluate). Instrumen yang digunakan pada penelitian ini adalah lembar validasi, penilaian guru, penilaian siswa, observasi keterlaksanaan pembelajaran, soal kemampuan pemecahan masalah, dan angket rasa ingin tahu. Perangkat pembelajaran dikatakan efektif jika persentase siswa yang memenuhi ketuntasan secara klasikal tes kemampuan pemecahan masalah minimal mencapai $75 \%$, dan jika persentase hasil angket rasa ingin tahu siswa memenuhi kategori tinggi minimal 75\%. Tahap awal pada penelitian adalah dengan melakukan tahap analisis dengan langkah melakukan analisis kebutuhan, analisis materi, dan analisis karakter siswa. Dalam tahap ini, dirancang RPP dan LKS dengan model learning cycle $7 e$ pada semester genap. Untuk menentukan kriteria kevalidan digunakan lembar validasi berdasarkan penilaian para ahli. Kemudian untuk kriteria kepraktisan digunakan lembar penilaian guru, siswa, dan observasi keterlaksanaan pembelajaran. Selanjutnya untuk menentukan kriteria keefektifan dilihat dari hasil nilai siswa dengan memberikan soal kemampuan pemecahan masalah dan angket rasa ingin tahu.
\end{abstract}

Kata Kunci: Model Leaning Cycle 7e, Perangkat Pembelajaran

Dalam proses pembelajaran matematika, terdapat 4 tujuan dari pendidikan matematika (Wijaya, 2012: 7). Pertama tujuan praktis yang berkaitan dengan pengembangan kemampuan siswa untuk menggunakan matematika dalam menyelesaikan masalah sehari-hari. Kedua tujuan kemasyarakatan yang berorientasi pada kemampuan siswa untuk berpartisipasi secara aktif dan cerdas 
dalam hubungan kemasyarakatan. Ketiga tujuan professional yang menyiapkan siswa untuk terjun ke dunia kerja. Keempat tujuan budaya dengan menempatkan matematika sebagai hasil kebudayaan manusia dan sekaligus proses mengembangkan kebudayaan. Ketika tujuan tersebut dapat dipenuhi, maka akan diperoleh siswa yang tidak hanya cerdas secara akademis dalam bidang matematika namun juga peduli terhadap lingkungan dan masa depan.

Berdasarkan tujuan penggunaan matematika dalam menyelesaikan masalah sehari-hari, maka sangat diperlukan kemampuan pemecahan masalah bagi setiap siswa. Krulik \& Rudnic (1995: 4) menyebutkan "problem Solving is the means by which an individual uses previously acquired knowledge, skills, and understanding to satisfy the demands of an unfamiliar situation". Pernyataan tersebut dapat dipahami bahwa pemecahan masalah dimaknai dengan dimana seseorang menggunakan pengetahuan yang diperoleh sebelumnya, keterampilan, dan pemahaman untuk memenuhi tuntutan dari situasi yang tidak biasa. Kemampuan pemecahan masalah akan diperoleh ketika siswa menggunakan pemikirannya. Hal ini sejalan dengan pendapat Nitko \& Brookhart (2011: 222) yang menyatakan "problem solving refers to the kind of thinking required when reaching a goal is not automatic and students must use one or more higher order thinking processes to do it". Pemecahan masalah sama halnya dengan berpikir untuk mencapai tujuan yang tidak diperoleh secara otomatis dan membutuhkan proses berpikir tingkat tinggi. Proses berpikir tingkat tinggi tersebut berguna untuk mengetahui mana cara yang tepat dalam mencapai tujuan yang hendak diperoleh.

Kemampuan pemecahan masalah sangatlah penting, namun dalam kegiatan pembelajaran terdapat beberapa kendala. Kendala tersebut dapat dilihat dari serangkaian kegiatan observasi yang dilakukan peneliti. Berdasarkan hasil observasi yang dilakukan di MAN 3 Sleman, ketika guru memberikan soal yang baru bagi siswa atau berupa soal cerita, siswa terlihat mengalami kesulitan dalam mengerjakan soal tersebut. Kesulitan yang dialami siswa ditunjukkan dengan lamanya siswa dalam mengerjakan soal karena tidak memahami permasalahan yang disajikan, banyak siswa yang melihat hasil kerja teman lainnya dan bahkan mencontet, sebagian besar siswa mengeluh tidak mengetahui prosedur penyelesaian yang akan digunakan, dan suasana kelas yang menjadi kurang nyaman karena munculnya keributan. Hal ini juga didukung dari hasil analisis kebutuhan yang dilakukan oleh Zulfah (2017: 7) bahwa kemampuan pemecahan masalah siswa masih perlu diperhatikan dan ditingkatkan. Perlu adanya upaya dalam mengembangkan kemampuan pemecahan masalah melalui perangkat pembelajaran yang mendukung seperti LKPD untuk mengarahkan siswa dalam upaya pemecahan masalah.

Selain observasi, peneliti juga melakukan wawancara terhadap beberapa orang guru matematika di MAN 3 Sleman mengenai kemampuan pemecahan masalah siswa. Berdasarkan hasil wawancara, diperoleh informasi bahwa ketika siswa diberikan latihan berupa soal-soal, beberapa siswa berpatokan pada contoh soal yang ada. Selanjutnya, jika diberikan soal yang sedikit dimodifikasi dari contoh sebelumnya, siswa terlihat bingung dalam menyelesaikan persoalan tersebut dan masih ada siswa yang melihat hasil pekerjaan teman. 
Dalam proses pembelajaran, yang tak kalah penting untuk ditingkatkan adalah rasa ingin tahu siswa terhadap matematika. Rasa ingin tahu adalah sikap dan tindakan yang selalu berupaya untuk mengetahui lebih mendalam dan meluas dari sesuatu yang dipelajarinya, dilihat, dan didengar (Kemendiknas, 2010: 42). Rasa ingin tahu terkadang mendorong siswa untuk melakukan suatu pengamatan atau penyelidikan. Hal ini biasanya berkaitan dengan perilaku siswa seperti mengeksplorasi, antusias dalam mengikuti pembelajaran, dan bersemangat dalam mengerjakan tugas.

Namun untuk memupuk rasa ingin tahu pada diri siswa tidaklah mudah, sehingga guru perlu membantu siswa demi mengoptimalkan kemampuan tersebut. Berdasarkan hasil pra-penelitian dengan memberikan angket rasa ingin tahu terhadap pembelajaran matematika kepada 32 orang siswa, diperoleh data bahwa rata-rata skor rasa ingin tahu siswa terkategori sedang. Adapun hasil perolehan data angket tersebut disajikan pada tabel 1 berikut.

\section{Tabel 1.}

Hasil Angket Rasa Ingin Tahu Siswa Pra-Penelitian

\begin{tabular}{|c|c|c|c|}
\hline Interval Skor & Kriteria & Jumlah siswa & Kondisi Awal \\
\hline$X>120$ & Sangat Tinggi & 0 & $0 \%$ \\
\hline $100<X \leq 120$ & Tinggi & 6 & $18,75 \%$ \\
\hline $80<X \leq 100$ & Sedang & 14 & $43,75 \%$ \\
\hline $60<X \leq 80$ & Rendah & 11 & $34,38 \%$ \\
\hline$X \leq 60$ & Sangat Rendah & 1 & $3,13 \%$ \\
\hline Rata-rata & Sedang & $\mathbf{3 2}$ & $\mathbf{8 4}$ \\
\hline
\end{tabular}

Selain angket yang diberikan, peneliti juga melakukan observasi kelas dan wawancara. Dari hasil observasi kelas, terlihat guru memberikan soal latihan kepada siswa. Siswa yang kurang memahami soal yang diberikan malu bertanya kepada guru, bahkan ada siswa yang diam saja. Ketika guru menuliskan kesimpulan dari materi pelajaran, hanya beberapa siswa yang membuka buku untuk mencatat poin tersebut, selebihnya menulis setelah diperintah oleh guru.

Kemudian berdasarkan hasil wawancara, guru mengatakan bahwa siswa belum aktif dalam mencari berbagai sumber belajar. Sebagian besar siswa masih menjadikan guru sebagai satu-satunya sumber belajar. Kemudian kurangnya antusias dan partisipasi siswa dalam kegiatan belajar di kelas. Dari hal tersebut terdapat indikasi bahwa masih rendahnya rasa ingin tahu siswa terhadap pembelajaran matematika.

Terhadap rendahnya kemampuan pemecahan masalah matematika dan rasa ingin tahu siswa tersebut, maka perlu mendapatkan perhatian dan solusi. Adapun cara yang dapat dilakukan adalah dengan melaksanakan perbaikan pada proses pembelajaran. Proses pembelajaran akan berjalan dengan baik jika perangkat pembelajaran yang digunakan telah dipersiapkan dengan baik.

Perangkat pembelajaran merupakan alat yang digunakan dalam proses pembelajaran (Trianto, 2009: 201). Perangkat pembelajaran dapat berupa silabus, rencana pelaksanaan pembelajaran (RPP), lembar kegiatan siswa (LKS), instrumen evaluasi atau tes prestasi belajar (TPB), media pembelajaran, serta buku ajar. Pada pelaksanaannya, LKS memiliki peran penting dalam mengorganisir proses 
pembelajaran. Hal ini sesuai dengan pendapat McArdle (2010: 169) yang mengatakan "worksheet is a way of organizing a picture of the training activity that becomes an important part of your module and lesson design". Ini berarti bahwa LKS merupakan suatu cara untuk mengorganisir kegiatan pembelajaran yang menjadi bagian penting dari modul dan rencana pembelajaran yang dirancang. LKS yang dirancang hendaknya dapat menumbuhkan semangat siswa dalam belajar. LKS yang dirancang akan dipadukan dengan model learning cycle $7 e$.

Sesuai dengan namanya learning cycle $7 e$, maka model ini memiliki 7 tahapan atau fase, adapun tahapannya adalah elicit, engage, explore, explain, elaborate, evaluate, dan extend (Einsenkraft, 2003: 57). Pembelajaran dengan siklus belajar merupakan salah satu model pembelajaran dengan pendekatan konstruktivis (Wena, 2009: 170). Kontruktivisme merupakan pandangan yang menekankan pada peran aktif pembelajar dalam membangun pemahaman dan memahami informasi (Woolfolk, 2009: 145).

Penyusunan LKS dengan model ini diharapkan mampu meningkatkan pemahaman dan mengembangkan kemampuan matematika siswa. Wijaya (2009: 3) mengatakan "learning cycle model is a learning model that encourages students to develop their own understanding of a scientific concept, explore and deepen that understanding, and then apply the concept to new situations". Model siklus belajar adalah model pembelajaran yang mendorong siswa untuk mengembangkan pemahaman mereka sendiri mengenai konsep ilmiah, mengeksplorasi dan memperdalam pemahaman tersebut, dan kemudian menerapkan konsep tersebut pada situasi baru. Peneliti merasa perlu mengembangkan LKS dengan model ini karena lebih menekankan pada kapasitas siswa dalam proses saintifik untuk memperoleh pengetahuan atau pengalaman belajar yang bermakna berbasis kontruktivis. Siswa sendiri yang mengkonstruk pengetahuan melalui pengalaman yang dimiliki. Sebagaimana belajar tidak hanya sekedar menghapal materi, namun lebih kepada proses mengkontruksi pengetahuan melalui pengalaman.

Penyajian masalah pada LKS ini akan dibuat secara realistik dan kontekstual dengan disertai gambar-gambar yang menarik. Sehingga akan menumbuhkan rasa tertarik siswa dan mengasah kemampuan pemecahan masalah siswa. Permasalahan yang disajikan akan melalui serangkaian tahapan seperti memahami masalah, mengumpulkan informasi, menentukan cara yang tepat dalam memecahkan suatu masalah yang dilakukan secara sistematis dan melakukan pengecekan terhadap jawaban yang diperoleh melalui metode ilmiah untuk memperoleh jawaban terbaik. Rencana pembuatan LKS dengan orientasi pemecahan masalah ini sejalan dengan penelitian yang dilakukan Hidayat dan Irawan (2017: 51). Namun dalam pelaksanaan penelitiannya, mereka menggunakan LKS berbasis RME dengan pendekatan pemecahan masalah. Berdasarkan hasil postes yang diberikan diketahui bahwa kemampuan pemecahan masalah matematika siswa sudah tergolong baik dengan persentase 79,14\%. Di dalam LKS, siswa diarahkan untuk mengolah masalah kontekstual menggunakan bahasa atau model dan simbol yang dibuat sendiri oleh siswa. Terlebih dahulu siswa 
menyelesaikan masalah tersebut dengan cara mereka masing-masing. Setelah itu, dilakukan proses menuju pada perumusan matematika formal.

Setiap langkah atau tahapan dari jawaban siswa telah diarahkan untuk memenuhi indikator dari kemampuan pemecahan masalah yang telah dibuat. Siswa akan dibimbing melalui petunjuk yang ada pada lembar LKS. LKS juga dirancang dengan model learning cycle 7e. Dengan demikian, diharapkan penggunaan LKS ini dapat menumbuhkan rasa ingin tahu dan meningkatkan kemampuan pemecahan masalah matematika siswa.

\section{METODE}

Penelitian ini merupakan penelitian pengembangan. Model pengembangan yang digunakan adalah model ADDIE. Model tersebut merupakan singkatan dari analyze, design, develop, implement, dan evaluate (Branch, 2009: 1). Pada tahap awal dilakukan analisis (analyze). Pada tahap analisis terdapat 3 hal yang dilakukan, antara lain analisis kebutuhan, analisis materi, dan analisis karakter siswa.

Analisis kebutuhan dilakukan untuk mengetahui permasalahan yang dihadapi siswa terhadap pembelajaran matematika, terutama pada materi trigonometri 1 untuk siswa kelas X SMA. Hal ini dibutuhkan untuk mengembangkan perangkat pembelajaran yang akan disusun agar dapat mendukung kegiatan belajar siswa. Kegiatan ini dilakukan melalui wawancara dengan guru matapelajaran matematika dan observasi terkait perangkat pembelajaran yang digunakan.

Setelah melakukan analisis kebutuhan, maka dilanjutkan dengan melakukan analisis materi. Analisis materi dilakukan untuk menentukan materi yang akan digunakan pada penelitian. Adapun materi yang digunakan adalah materi trigonometri 1 untuk siswa kelas X SMA. Selain menentukan materi, perlu ditetapkan kompetensi inti (KI), kompetensi dasar (KD), indikator dan tujuan pembelajaran. Analisis ini merupakan dasar dalam pengembangan Rencana Pelaksanaan Pembelajaran (RPP), Lembar Kegiatan Siswa (LKS) dan instrumen penilaian yang disesuaikan dengan kurikulum 2013 revisi.

Kemudian melakukan analisis karakter siswa, hal ini dilakukan untuk mengetahui karakteristik siswa seperti perkembangan kognitif yang disesuaikan dengan materi pembelajaran yang akan digunakan. Analisis dilakukan melalui tanya jawab dengan guru matematika yang mengajar pada kelas X SMA. Hal ini berguna dalam merancang perangkat pembelajaran dan pembentukan kelompok saat siswa berdiskusi pada proses pembelajaran.

\section{HASIL DAN PEMBAHASAN}

Tahap pertama yang dilakukan adalah analisis. Analisis dilakukan pada siswa kelas X MAN 3 Sleman. Tahap ini terdiri dari analisis kebutuhan, analisis materi, dan analisis karakter siswa. 


\section{Hasil Analisis Kebutuhan}

Berdasarkan hasil analisis kebutuhan diperoleh data bahwa kemampuan pemecahan masalah siswa juga masih tergolong rendah. Hal ini terlihat dari data hasil daya serap UN pada materi trigonometri, hasil observasi, hasil wawancara peneliti dengan guru matematika di MAN 3 Sleman, dan hasil pra-penelitian yang dilakukan peneliti. Selanjutnya untuk rasa ingin tahu siswa tergolong sedang. Data ini diperoleh dari hasil pra-penelitian, sedangkan berdasarkan hasil observasi dan wawancara peneliti dengan guru matematika di MAN 3 Sleman diperoleh informasi bahwa rasa ingin tahu siswa masih tergolong rendah.

Selain itu, peneliti juga melakukan wawancara dan memberikan kuisioner kepada 10 orang guru. Hal ini dilakukan untuk mengetahui perangkat pembelajaran yang selama ini digunakan guru dalam proses pembelajaran. Dari hasil wawancara dan kuisioner tersebut diperoleh informasi bahwa 7 dari 10 orang guru menyusun RPP dengan mengadaptasi dari hasil MGMP dan mengunduh dari internet, sedangkan 3 lainnya menyusun RPP sendiri. Guru masih jarang menyusun perangkat pembelajaran yang berorientasi pada kemampuan pemecahan masalah dan rasa ingin tahu siswa. Selanjutnya, belum ada guru yang mengembangkan perangkat pembelajaran seperti RPP dan LKS dengan model learning cycle $7 e$ untuk mendukung kegiatan pembelajaran.

Dari pemaparan di atas, diperoleh informasi bahwa kemampuan pemecahan masalah dan rasa ingin tahu siswa terhadap pembelajaran matematika masih tergolong rendah. Kemudian, contoh perangkat pembelajaran dengan model learning cycle $7 e$ yang belum tersedia, sehingga guru juga belum pernah menyusun perangkat dengan model tersebut. Oleh sebab itu diperlukan pengembangan perangkat pembelajaran berupa RPP dan LKS dengan model learning cycle $7 e$ untuk memfasilitasi guru dan siswa dalam proses pembelajaran dengan kegiatan penyelidikan yang memberdayakan kemampuan berpikir siswa. Dengan demikian, kemampuan pemecahan masalah dan rasa ingin tahu siswa terhadap matematika memperoleh hasil yang lebih baik.

\section{Hasil Analisis Materi}

Analisis materi dilakukan untuk mengetahui materi yang digunakan. Pada penelitian ini materi yang digunakan adalah materi trigonometri 1 pada semester genap untuk siswa kelas X SMA. Pengembangan perangkat pembelajaran diterapkan berdasarkan kurikulum 2013 revisi. Kurikulum 2013 revisi memuat kompetensi inti (KI) dan kompetensi dasar (KD). Berikut disajikan KI dan KD yang digunakan pada penelitian dengan materi trigonometri 1 pada tabel 2 berikut.

\section{Tabel 2.}

Kompetensi Dasar Materi Trigonometri SMA kelas X Kurikulum 2013 Revisi

\begin{tabular}{|c|c|}
\hline $\begin{array}{c}\text { Kompetensi Inti } 3 \text { (Pengetahuan) } \\
\text { Kompetensi Dasar }\end{array}$ & $\begin{array}{c}\text { Kompetensi Inti } 4 \text { (Keterampilan) } \\
\text { Kompetensi Dasar }\end{array}$ \\
\hline $\begin{array}{l}\text { Menjelaskan rasio trigonometri (sinus, } \\
\text { cosinus, tangen, cosecan, secan, dan } \\
\text { cotangen) pada segitiga siku-siku }\end{array}$ & $\begin{array}{l}\text { 4.7 Menyelesaikan masalah kontekstual yang } \\
\text { berkaitan dengan rasio trigonometri } \\
\text { (sinus, cosinus, tangen, cosecan, secan, } \\
\text { dan cotangen) pada segitiga siku-siku }\end{array}$ \\
\hline
\end{tabular}




\begin{tabular}{|c|c|}
\hline $\begin{array}{l}\text { 3.8 Menggeneralisasi rasio trigonometri } \\
\text { untuk sudut-sudut di berbagai kuadran } \\
\text { dan sudut-sudut berelasi }\end{array}$ & $\begin{array}{l}\text { 4.8 Menyelesaikan masalah kontekstual yang } \\
\text { berkaitan dengan rasio trigonometri } \\
\text { sudut-sudut di berbagai kuadran dan } \\
\text { sudut-sudut berelasi }\end{array}$ \\
\hline
\end{tabular}

Pemilihan materi ini sudah berdasarkan diskusi dengan guru matematika di MAN 3 Sleman. Trigonometri merupakan materi yang dirasa sulit bagi siswa. Hal ini dikarenakan banyaknya rumus yang digunakan dan soal cerita yang terkadang membingungkan siswa. Kemudian guru juga menambahkan, dari pengalaman yang terdahulu, jumlah siswa yang mengikuti remedial setelah ulangan harian mengenai materi ini juga masih banyak. Sehingga peneliti merasa perlu mengembangkan LKS yang dapat membantu siswa dalam menghadapi kesulitan tersebut.

\section{Hasil Analisis Karakter Siswa}

Berdasarkan perkembangan kognitif siswa, maka siswa SMA berada pada tahapan operasional formal. Pada tahapan ini siswa telah mampu bernalar, berpikir secara abstrak, dan menggunakan logika. Sehingga siswa telah mampu diberikan masalah rutin maupun non rutin. Masalah yang disajikanpun mengarah pada masalah kontektual dan realistik.

Kemudian berdasarkan hasil observasi dan wawancara yang dilakukan, para siswa lebih suka belajar dalam kelompok yang terdiri dari 3 sampai 4 orang. Hal ini terlihat pada saat proses pembelajaran berlangsung, ketika siswa belum memahami materi yang dijelaskan oleh guru, maka sebagian besar siswa lebih suka bertanya dengan temannya. Hal ini dikarenakan beberapa siswa ada yang malu dan tidak berani bertanya langsung kepada guru.

Berdasarkan hasil analisis karakter siswa tersebut, maka perlu dikembangkan LKS dengan model learning cycle $7 e$ agar dapat membantu siswa dalam belajar dan memecahkan masalah. Berdasarkan tahap perkembangan siswa, hasil observasi dan wawancara, maka peneliti ingin mengembangkan LKS dengan model learning cycle $7 e$ yang mengarahkan pada kegiatan eksplorasi untuk menemukan konsep yang menjadi tujuan pembelajaran. Melalui penemuan konsep tersebut, siswa diarahkan untuk dapat menyelesaikan permasalahan yang diberikan dan menuntun siswa untuk lebih aktif mengkonstruksi pengetahuannya secara mandiri.

\section{KESIMPULAN}

Berdasarkan pemaparan pada tahap analisis di atas, maka diperoleh kesimpulan bahwa dalam proses pembelajaran dibutuhkan perangkat pembelajaran yang mendukung. Perangkat tersebut perlu dipersiapkan agar terlaksananya proses pembelajaran yang sesuai dengan rencana. Selain itu, perangkat pembelajaran juga harus mampu membantu memfasilitasi siswa dalam belajar.

Materi yang akan dipelajari siswa dalam penelitian ini adalah mengenai trigonometri 1. Materi trigonometri ini dirasa sulit oleh sebagian besar siswa. Hal ini dikarenakan pada materi trigonometri tersebut memiliki banyak rumus dan soal-soal cerita yang terkadang sulit dipahami oleh siswa. Sebagian besar dari rumus tersebut sulit untuk diingat. Oleh sebab itu, siswa membutuhkan 
bantuan dalam memahami materi tersebut tanpa harus menghapal rumus-rumus tersebut dan siswa juga membutuhkan cara untuk memahami kata kunci yang harus diketahui siswa dalam menyelesaikan soal cerita.

Kemudian dalam proses pembelajaran yang juga perlu diperhatikan adalah kemampuan yang diperoleh siswa setelah mengikuti kegiatan belajar. Salah satunya adalah kemampuan pemecahan masalah matematis siswa. Untuk membantu siswa dalam mengembangkan kemampuan pemecahan masalah, maka siswa harus dibiasakan dalam mengerjakan latihan atau menjawab soal-soal yang dapat mengasah kemampuan mereka hingga ditemukan solusi penyelesaian. Kemudian guru juga perlu memfasilitasi siswa dengan penggunaan LKS. LKS yang diberikan hendaknya dapat membantu siswa dalam memahami materi pelajaran dan diharapkan mampu mengkontruksi pengetahuan dan memperoleh pengalaman belajar. Dalam hal ini LKS yang digunakan akan dipadukan dengan model learning cycle $7 e$.

Model learning cycle $7 e$ penting diterapkan dalam pembelajaran karena lebih menekankan pada kapasitas siswa dalam proses saintifik untuk memperoleh pengetahuan atau pengalaman belajar yang bermakna berbasis kontruktivis. Siswa sendiri yang mengkonstruk pengetahuan melalui pengalaman yang dimiliki. Sebagaimana belajar tidak hanya sekedar menghapal materi, namun lebih kepada proses mengkontruksi pengetahuan melalui pengalaman. Diharapkan penggunaan LKS dengan model ini dapat membantu siswa dalam memahami materi, mengembangkan kemampuan pemecahan masalah matematika dan menumbuhkan rasa ingin tahu terhadap pembelajaran matematika.

\section{DAFTAR PUSTAKA}

Branch, R.M. (2009). Instructional design: The ADDIE approach (Vol. 722). Athens, GA: Springer Science \& Business Media.

Einsenkraft, A. (2003). Expanding the 5E model. Science Teacher-Washington, 70 (6), 56-59.

Hidayat, A \& Irawan, I. 2017. Pengembangan LKS Berbasis RME dengan Pendekatan Problem Solving untuk Memfasilitasi Kemampuan Pemecahan Masalah Matematis Siswa. Journal Cendekia: Jurnal Pendidikan Matematika. 1 (2), 51-63.

Kemendiknas. (2010). Pengembangan pendidikan budaya dan karakter bangsa. Jakarta: Badan Penelitian dan Pengembangan Pusat Kurikulum.

Krulik, S. \& Rudnick, J.A. (1995). The new sourcebook for teaching reasoning and problem solving in elementary school. A longwood professional book. Needham, Massachustts: Allyn \& Bacon.

McArdle, G.E. (2010). Instructional design for action learning. Broadway, New York: AMACOM Div American Mgmt Assn.

Nitko, A.J., \& Brookhart, S.M. (2011). Educational assessment of students (6 $6^{\text {th }}$ ed). Upper Saddle River, New Jersey: Pearson Education. 
Trianto. (2009). Mendesain model pembelajaran inovatif-progresif: konsep, landasan, dan implementasinya pada kurikulum tingkat satuan pendidikan (KTSP). Jakarta: Kencana Prenada Media Group.

Wena, M. (2009). Strategi pembelajaran inovatif kontemporer. Jakarta: Bumi Aksara.

Wijaya, A. (2009). Learning cycle model. Workshop on developing learning model based on realistic mathematics education approach, Regional Center of Qitep in Mathematics.

Woolfolk, A. (2009). Educational psychology active learning edition. Edisi kesepuluh bagian kedua. (Terjemahan Helly Prajitno Soetjipto \& Sri Mulyantini Soetjipto). Boston, Massachusetts: Pearson education.

Zulfah. 2017. Tahap Preliminary Research Pengembangan LKPD Berbasis PBL untuk Materi Matematika Semester 1 Kelas VIII SMP. Journal Cendekia: Jurnal Pendidikan Matematika. $1(2), 1-12$. 